\title{
Persuasive speech acts in the Namibian National Assembly
}

\author{
Justina Meluwa Latenda Amakali \\ University of Namibia, P/Bag 13301, 340 Mandume Ndemufayo Ave. Pioneers Park, Windhoek, Namibia
}

\begin{abstract}
This paper examined the speech acts used by Namibian Members of Parliament (MPs) during parliamentary proceedings. The main aim of this paper was to explain speech acts and show their intended persuasive effects in parliamentary discourse. Austin (1962) introduced three types of speech acts, locutionary, illocutionary and perlocutionary. The paper attempted to critically demonstrate how MPs use persuasion strategies in their debates. These speech acts were uttered through assertives, directives, commissives, expressives, and declaratives, as classified by Searle (1969). A qualitative approach was used in this paper whereby the Hansard were used to collect data. A purposeful sampling focusing on some MPs was used. This paper was guided by two theories, Austin's Speech Act Theory and Aristotle's Theory of Rhetoric. The need to apply rhetorical skills in debates is widely advocated for. Although not all members of parliament have a wide knowledge of rhetoric, acquiring and employing skills on rhetoric are prominent aspects of parliamentary debates. The findings of the paper revealed that members of parliament have the potential to use a variety of persuasive strategies in their speech acts by means of some rhetorical devices. It was concluded that most MPs deliberately make use of these speech acts as a persuasive mechanism in their discourse. Being the first study in parliamentary discourse in Namibia with regards to rhetoric, it is considered to be unique and adds value in the field of linguistics. It also serves as a pioneering research to researchers in political rhetoric.
\end{abstract}

\section{Indexing terms/Keywords}

Speech acts, Speech Act Theory, Aristotle's Theory of Rhetoric, Rhetorical devices, Members of Parliament.

\section{Academic Discipline And Sub-Disciplines}

Linguistics: Rhetoric

\section{SUBJECT CLASSIFICATION}

Speech acts

\section{TYPE (METHOD/APPROACH)}

\author{
Qualitative Analysis
}

\section{INTRODUCTION AND BACKGROUND}

Speech is an essential tool and mode of communication in politics. It is a vessel through which politicians express their views, opinions, discussions and the decisions they make as lawmakers towards the development of a country. According to (Ayeomoni \& Akinkuolere, 2012), "most activities performed by politicians are done through the avenue created by language" (p. 461). Such an avenue could be that of parliamentary interaction in which language plays an important role.

In general terms, this paper discusses Parliamentary rhetoric. The paper mainly aims at analysing speech acts in the Namibian National Assembly and the way they were used to persuade. According to Palonen (2016), "Parliamentary rhetoric is a historically powerful example of deliberative rhetoric" (p. 20). The Namibian parliament uses the Westminster system and follows all its regulations. De Mille (as cited in Palonen, 2016) states that the Westminster was the first to develop the distinct parliamentary subgenre of deliberative rhetoric. Namibia's official language in parliament is English and it is the language used for both debates and documentation purposes such as the Hansard. The Hansard is the official verbatim published report of the debates and proceedings in the parliament of a member of the commonwealth. Parliamentarians attempt to persuade their audience in different ways via different rhetorical devices and this is where rhetoric is concerned. Parliamentary discourse has become an important field of study. In fact, few studies have been conducted on speech acts used by members of parliament.

As lawmakers, MPs contribute immensely to the good governance of a society because of their input in decision making. For this reason, parliamentary discourse should be a factor of good governance. Parliamentary discourse consists of debating issues, proposing, amending, and passing of bills. Generally, any formal or informal conversation is composed of different types of speech acts. Austin (1962) introduced three types of speech acts, namely: locutionary act, illocutionary act and perlocutionary act. He defines the locutionary act as the act of uttering something. In addition, he defines the illocutionary act as the intentional meaning of what was uttered while the perlocutionary act is the act of doing something by being prompted by the illocutionary act. While they present their speeches via debates, MPs are usually unaware that most of the speech acts they use are either locutionary, illocutionary or perlocutionary acts.

During parliamentary debates, members of parliament express themselves through different kinds of speech acts to persuade other members of parliament and the public to concur with their points of view. Of course these expressions should be given in a procedural manner based on the system that the parliament uses. On the question of what makes a parliament, De Mille (as cited in Palonen, 2016) claims that procedure is what constitutes parliamentary an institutionalised 
activity. It is, therefore, crucial to use good skills of rhetoric in their command of language in achieving this goal. According to (Habinek, 2005), "even the rise of specialized speech-writers at Athens, or the reliance on well-connected patrons at Rome, is indicative of the importance of rhetorical speech and of the need to master it, either directly or indirectly" (p. 4). Jarraya (2013) emphasises that linguistic persuasive strategies should not be used single-handedly, especially when there is tension, but should be accompanied by other non-linguistic devices like the personality of the persuader, and a solid understanding of the socio-political context.

To gain a solid understanding of these speech acts, a qualitative approach was used. The population of the study was Namibian members of parliament. The Namibian parliament comprises 104 members. The sample was purposeful sampling focusing on members of parliament uttering speech acts. Data was collected by using the Hansard's transcription. From the data collected, the researcher identified some speech acts that embrace persuasive devices used by members of parliament. It should be noted that all speech acts of MPs used in this paper were taken from the Hansard's volumes and written as they appear in the Hansard.

According to Langton (1993), the capability of performing various speech acts can be a sign of political power. Langton (1993) further states that powerful people are able to do and say more and be more dominant in speech than others. The positions and roles of the MPs are indicated at the end of the paper in the appendix.

\section{THEORETICAL FRAMEWORK}

Two prominent theories informed this research study: Austin's theory of speech act and Aristotle's theory of rhetoric. Austin's theory of speech act argues that all utterances with their meanings perform specific actions through particular forces. Levinson (1983) states that Austin's notion by saying something one is doing something is guided by three acts that are simultaneously performed. These are locutionary, illocutionary, and perlocutionary acts. This theory was useful for this research because most of the statements made by the MPs are performatives. According to Levinson (1983) performatives are not utterances used to say things, but to actively perform actions. Nuccetelli and Seay (2008) state that a performative is a sentence-size expression used in a speech to do something other than to convey a content that is true or false; A constative is any statement carrying a message, for example declaratives. This implies that a constative does not necessarily have performance, however, each has a truth value either true or false. In this research, indirect speech acts are mostly used which make them rhetorical statements, thus a combination of the two theories, speech acts and rhetoric.

Aristotle's theory of rhetoric comprises three kinds of persuasion, namely: ethos (character), pathos (emotions), and logos (reasoning). According to llie (2003), "a message is expected to provide its audience with good and sufficient reasons to believe and to act" (p. 255), this is what Aristotle called logos. Furthermore, llie (2003) states that when the authority of the speaker guarantees the audience of credibility in the message, this is rhetorically identified as ethos. Then, she states that pathos refers to the emotions felt by the audience; therefore, the message should convincingly engage the audience.

Aristotle's theory was useful for this paper since the rhetorical devices used by MPs are part of the three appeals of persuasion. The theory helped the researcher to logically relate these three appeals to the real discourse that took place in parliament and interpreted them accordingly. With reference to Aristotle's theory, llie (2010) stresses that "parliamentary discourse is shaped by means of institution-based rhetorical devices through the participants' ongoing adjustment and readjustment to proceeding speakers and discourses, to their own prior discourses to the audience's cognitive and information background, as well as expectations" (p. 59). Ilie (2002) states that in order to study the rhetorical strategies that motivate parliamentary meta-discourse, "it is necessary to distinguish theoretically and practically three major components of a rhetorically tailored message, logos, ethos and pathos" (p. 80). Rorty (1996) advocates for what he calls an Aristotelian solution that "a successful rhetorician structures his speech to elicit emotions that are connected with stable motivational structures" (p. 21).

\section{RHETORICAL DEVICES USED IN PARLIAMENTARY PROCEEDINGS}

In these debates, most of the speech acts were made in order to achieve persuasion via negotiations, dissensus, compliments, sarcasm, etc. Palonen (2016) consents by pointing out that, negotiations have a major role in parliamentary agreements between parties or the government and its oppositions. This paper shows that different kinds of persuasive strategies were used in parliament by means of speech acts which aim at persuading their audience. Palonen further states that such negotiations tend to strengthen or weaken the deliberative essence of parliamentary rhetoric.

In the following sections, are speech acts used by some Namibian MPs. These utterances were extracted from four volumes of the Hansard. They were selected from different topics of parliamentary agenda; therefore they are not necessarily linked. The sampling of this study was done on the basis of the relevant persuasive speech acts required for the study. Seven rhetorical devices were selected under which these speech acts were discussed, namely: Questions, Evidence, Inclusive language, Anecdote, Attacks and Praises, Metaphor, and Emotional Appeal.

\section{Questions}

Questions play a major role in parliament. There are two kinds of questions, direct and indirect questions. In parliamentary debates, rhetorical questions often occur as two-way streets. They can be posed by the official speaker or they may come from the audience as an interruption. Rhetorical questions often do not require answers, but stand as statements (although they appear as questions) made by the speaker to put emphasis on the status quo. According to Frank (1990), "the rhetorical tactic of posing questions that expect no answer is historically well known to be an effective persuasive 


$$
\begin{array}{r}
\text { ISSN 2348-3024 } \\
\text { Jolume } 7 \text { Number } 2 \\
\text { Journal of Advances im Linguistics }
\end{array}
$$

device and one which influential speakers continue to use today" (p.723). Rhetorical questions may be speech acts which indirectly request, command, order, suggest, propose or advise. Most of the rhetorical questions tend to be performatives because of their nature of action as mentioned in the latter. Chen (2006) claims one crucial factor that should be taken into consideration when using rhetorical questions is the relative power or status of the speaker over the hearer. Chen (2006) further argues that a rhetorical question is used as a proposal and request by a speaker of higher status. For example, the following question was posed by Honourable Tweya in disappointment of the kind of management at Air Namibia:

Hon. Tweya: "What type of management is this?"

Tweya used the question, which does not necessarily need an answer, to imply that the management under discussion is not being carried out well, and also to alert or warn the people involved regarding the situation. The audience is likely to have picked up the negative connotation attached to the management question and is thus convinced that it is poor or bad management which requires improvement. According to (Kangira \& Mungenga, 2012), "those who use rhetoric use it to influence other people to follow their good or bad intentions" (p. 110). Honourable Tweya, as the head of the Ministry of Information and Technology (Minister), possesses the authority to question or order his subordinates to use good management skills in the ministry. Therefore, it can be concluded that this kind of question is posed by a senior member of the government who has power and indirectly gives an order. This utterance is a performative act because it prompts the target audience to take action with regards to the management. The intended meaning of the utterance which is the illocutionary act indirectly implies that the management is not appropriate, hence a rhetorical question. Similarly, Smit asked a question of which he does not necessarily require an answer, but emphasises the high rate of car accidents on the Namibian highway road:

Hon. Smit: "How many more people must be killed on that road?"

Smit, quite disappointed by reckless drivers, highlights the seriousness of accidents that occur on the road. To emphasise this issue, he ends his speech with a rhetorical question to notify the audience of the high fatality rate on a particular road. The rhetorical question is intended to persuade the people to change their behaviour and drive with due care and caution.

On the contrary, research shows that sometimes the speaker may give an immediate answer to his/her question as shown in the following statement:

Hon. Maamberua: How did this BBA come in this act? It has nothing to do with this act.

Although the question above is known as a hypophora and not necessarily rhetoric, its immediate answer pushes for persuasion. Mbenzi (2014) explains that the function of the hypophora is to give the rhetor a chance to question the opinions of the audience that oppose them or to get ahead and answer objections that might be made to their positions. In this case, the speaker does not give the audience time to consider the question, but provides a quick answer to indicate that the BBA is not supposed to be in the act. This is direct rhetoric which is commonly used when the speaker does not want the audience to object his point. Nabea (as cited in Mbenzi, 2014, p. 222), claims that "the answers are meant to persuade the reader/listener to buy the line of argument of the author, instead of being left free to carry self-evaluation of issues".

Han (2002) argues that "a rhetorical question has the illocutionary force of an assertion of the opposite polarity from what is apparently asked" (p. 201). In the question that follows, Venaani sarcastically asked his fellow MP this:

Hon. Venaani: Have you not gone to school?

This rhetorical question infers humiliation and shaming. It indicates that the person whom Venaani is responding to lacks some kind of information or is rather misinformed. The speaker in response wanted the audience or specific person to get their facts accurate. Venaani created the impression that the person is illiterate. Given that, the person Venani is referring to is likely to be persuaded to accept his viewpoint because she/he does not want to be labelled illiterate. She/he does not want to be embarrassed in public. The question is thus a face-threatening act (FTA) and may cause embarrassment to the interlocutor. O'Driscoll (2007) defines a face-threatening act as "any move which predicates a change in face" (p. 243). According to Chivero (2012), "question time in particular and discussion are highly aggressive genres and Face Threatening Acts (FTAs) are intrinsic to their essence" (p. 123).

Similarly, in the following question, Kavekotora posed a question and immediately hit back with a statement in order to trigger the audience to be on par with his opinion as shown below:

Hon. Kavekotora: What is the anchor or the basis of our Foreign Policy? I am asking this because I remember that way back in 2004 there was a White Paper on Namibian Foreign Policy and Diplomatic Management. Is this applicable today or not?

Mbenzi (2014) calls this, "reflecting together" with the rhetor. Kavekotora seems not to necessarily seek for the answer to the first question, but rather wants to show the relevancy of the Namibian Foreign Policy.

In a different dialogue, following are four rhetorical questions, which are speech acts that request, command, request, and state, respectively.

"Can we have respect for each other please?" (Tweya)

"Can you say that?" (Chairperson of the Whole House Committee) 
"Can we restore our economy?" (Tweya)

"Do I complain?" (Dienda)

Although they appear as questions, they are actually illocutionary acts that perform actions. First, Tweya clearly requested the house to have respect for one another and does not necessarily ask if the house can do that or not as the question appears to be. Second, the Chairperson of the Whole House Committee did not seek a yes or no answer from Dienda whether she could say it or not, instead he commands her to say it. Third, Tweya requested the house in a form of a question. And fourth, Dienda posed a question that infers that she does not complain when she is called Dienda. She uttered it as a question, but in reality it is a statement, as the response was not needed in that case. The first three questions are directives. Although they sound like questions, the speaker is indirectly telling the interlocutor to do something.

The following conversation was between the speaker and Honourable Dienda. Dienda who was hesitant to mention Honourable Calle Schlettwein's surname was commanded by the speaker to mention the surname and not to say difficult surname. The command was put in a form of a question, thus to make it polite and persuade Dienda to do so.

Hon. Dienda: Moreover, the items mentioned do not correlate with what was budgeted for in the Budget tabled by Honourable Calle difficult surname.

Hon. Tweya: Please but not Calle difficult surname. He does not have another surname. Can we have respect for each other, please?

Chairperson of the Whole House Committee: You listen to me; you can say Honourable Minister of Finance. Can you say that?

The Chairperson's statement has a force of a command. The perlocutionary act of this statement is that Dienda reacted to this command. One of the roles of the Chairperson is to determine which member may speak. He is also accountable for keeping order during debates; therefore he is in a position to command members. Such roles may be influential to his speech acts. This can be alluded to Chen's (2013) statement as mentioned earlier in this section. Dienda continued to refuse to mention Calle's surname:

Hon. Dienda: Honourable Minister of Finance, Honourable Calle.

Chairperson of the Whole House Committee: No, just say Honourable Minister of Finance.

Hon. Dienda: I want to be specific. Honourable Chairperson, he is the one calling me Dienda, Dienda every day. Do I complain?

In another conversation, Mbumba wanted to inform the audience that universities and research institutions should be established in additional cities throughout Namibia. He put it in a rhetorical question form, but he actually intended to inform them to attract Research Institutions. His speech act is an illocutionary act which gets the listener to perform a perlocutionary act.

Hon. Mbumba: We have places like Swakopmund, why can we not attract reputable Research Institutions and Reputable Universities to these places?

\section{Evidence}

Speech acts which are uttered as facts, statistics, research results, findings and experience may be regarded as evidence. Most of these statements are declaratives as they speak for themselves. By giving evidence, the speaker is performing an action, therefore, some evidence are performatives. However, some may be constatives as they state facts and may not have any performing actions when they are uttered. According to Mbenzi (2014), a statement of facts "consists in the persuasive exposition of that which either has been done or is supposed to have been done" (p. 176). In other words, Mbenzi gives Appollodorus' definition that it is "a speech instructing the audience as to the nature of the case in dispute" (p. 176). In most cases, the speaker displays logos as he reasons from the evidence s/he has. According to Jarraya (2013), "showing people that newly proposed beliefs are highly consistent with their established beliefs in terms of cause/effect, goal/means, space or time, can trigger their logical analysis and make their argumentation coherent in their minds" (p. 13). It may be concluded that speech acts with evidence are generally not determined by positions of MPs, however, the fact that they have access to the information given as evidence may mean this was brought about by the positions they possess.

In the following example, Jagger's last sentence is a speech act that tells that she was involved in the activity being discussed. She tried to give evidence that she worked in the programme, thus her knowledge of the signed contract:

Hon. Jagger: The Government has signed a contract with them and we have a Traditional Skills Development Programme that is running in Kunene, //Karas, and Otjozondjupa Regions and I am sure in Omusati Region as well. I worked with that Programme.

In order for her audience to accept her appeal, she directly stated that she has worked with the programme. Jagger appeals to the ethos of experience and authority. She is aware of the information and acquired experience when she worked with the programme. Informing people that you have experienced or were involved in a programme may enable the audience to look at the speaker as a credible and reliable person because of the assurance they are given. 
Another way of giving evidence verbally is to mention the date of the incidence. livula-Ithana, the Minister of Home Affairs, is well informed of the progress made in the passport and ID sections in the Ministry. As the head of the Ministry, she liberally informed the House of their successes at the Ministry and she mentioned the exact date when they started progressing. This is to show her audience that there is recorded information illustrating the progress. Ithana's role as a Minister encouraged the audience to consider her credibility as a good source of information. This evidence, being recorded in documents, may be regarded as a declarative speech act:

Hon. livula- Ithana: Significant progress has been made in the passport and ID sections since the 23rd of June 2014.

As stated early in this section, giving statistics also accounts for persuasion. In his short version, Nghimtina gave statistics of the employment rate as evidence to strengthen his budgetary proposal. These were the exact figures recorded by the Employment Equity Commission. Logos is applied here because Nghimtima gave a logical point with facts as evidence of the challenges he mentioned:

Hon. Nghimtina: Before indicating our budgetary requests for next year, I will address briefly the challenges faced in achieving employment equity. While reports received last year by the Employment Equity Commission revealed that $84 \%$ of the employees covered by the reports are black, white employees disproportionately occupy the higher level positions: $59 \%$ of CEO's and $34 \%$ of managers are white, while only $34 \%$ of managers are women and $1 \%$ are persons with disabilities.

Another way of giving evidence is by asserting information that one physical has at the moment. Following is an assertive speech act whereby the speaker shows the document with information that he gave.

Hon. Shanghala: They have provided adequate information as you can see.

To have something at hand as you speak seems to be persuasive as the audience is able to see and get the required information right away.

\section{Inclusive language}

According to Habinek (2005), rhetoric establishes a feeling of inclusion within participants. He points out that rhetoric involves participants in shared practices in which decisions are made regarding the community as a whole and its entire individual members. Pronouns such as we, us and our, are commonly used in speech when a speaker wants to show inclusivity of the other person or group. Using inclusive language is an effective way of persuading the audience as it makes them feel involved and creates the impression that the speaker is part of them. Karaliova (2015) claims that, "analysis of inclusive or exclusive solidarity rhetoric will help in understanding how common identities of particular nations are being constructed and how rhetorical means are being manipulated to create an image of unity and conformity" ( $p$. 147). This is a suitable strategy when the speaker is directly addressing their opponent especially when dealing with government related issues. According to Silvestre-Lopez (2004), usually, the politician uses the word 'we,' in order to create a close relationship with his audience. However, it should be noted that 'we' may also be used in an exclusive capacity when an MP refers to their specific group such as political party, cabinet, committee, etc.

The example below shows that the pronoun we refers to all members of parliament including Venaani himself. Although Venaani is one of the Opposition Party leaders, he uses the pronoun 'we' to show that he is not blaming the government alone, but he as an opposition leader includes himself and his party in sharing the blame.

Hon. Venaani: It tells a story that we are not prepared, we do not know what we are doing and we are just running around.

He says "we are not prepared", implying that he and other MPs are all included in this regard. It can be concluded that Venaani blamed the house, in which he included himself (a positive sign of being humble). Including himself will easily encourage the audience to accept the blame. He also appeals to the ethos of the audience since he indicates that he is part of the group. In a similar account, Jagger used the pronoun our to include the general public. She appealed to the audience's pathos by showing them that the MPs and the Namibian nation as a whole are considered the same in all aspects.

Hon. Jagger: Our people were dreaming about prosperity. We, therefore, need to dream together with the Namibian Electorate.

Jagger used the pronoun 'our' to display inclusivity and ensure that no one feels left out. This statement is crucial not only to the MPs, but also to the general public. The public through media viewing are made to believe that where prosperity is concerned, all Namibians are considered. Another inclusive pronoun used is us. Nandi-Ndaitwah used the words us and our to show the audience that she included all members of parliament regardless of their political parties as shown below:

Hon. Nandi-Ndaitwah: It is very important for us to make sure that we implement whatever we have agreed upon. That is where our refocus is.

Nandi-Ndaitwah wanted all members of parliament to feel that they were involved in the implementation of what they discussed. Kangira (2007) calls the aforesaid words Together-words. According to Kangira and Mungenga (2012), the function of together-words is to show that the speaker and the audience share the same beliefs and values. Some examples of together words that Kangira explained were united, we, us, common, Zimbabweans, consensus, ourselves, 
and our. Other examples of together-words are: our Government, our beautiful country, all of us, our nation, etcetera as given by (Kangira \& Mungenga, 2012). In a study he conducted, he states that together words were used to give a sense of common ownership of the problem at hand. The following assertive includes the word everybody which can be regarded as a together-word that shows the audience that the education and health provision given by foreign countries includes all and not only some citizens.

Hon. Mbumba: We have friends like the Germans, Russians, Chinese, Japanese and the Americans, and it is good that they are helping to ensure that everybody has a chance to go to school and have access to good health.

Another example of together words was given when the speaker mentioned two countries together to show the uniting of the two countries in terms of engaging in various activities.

Hon. Venaani: Can we not have days these Ambassadors who represent us, come to Namibia and have a Brazil/Namibia Day, for instance? Promoting these days, for example, Namibia/Kenya Day, Namibia/Tanzania Day, would help our people to really start thinking globally....

\section{Anecdote}

An anecdote is a personal story or experience that a person shares with his/her audience in order to entertain or interest them. An anecdote may be given in a form of exordium. Kangira and Mungenga (2012) define the exordium of a speech as "the introduction of the speech in which the speaker states the purpose of his speech" (p. 112). Speech acts with their different illocutionary forces such as to complain, suggest, advice, inform or order may be used in an anecdote in order to appeal to the pathos of the audience, and the logos and ethos of the speaker. According to Johnstone (1989), "analogical rhetoric persuades by teaching, reminding its audience of time-tested values by the indirect mode of storytelling" (p. 149). The following example is a narration of Venaani in an attempt to persuade the house to concur with his suggestion of providing the San people with job opportunities:

Hon. Venaani: I have a farm worker, perhaps just for the interest of the House, who is probably 57 now. He asked me one day; you people like elections, elections. Can I ask you something boss? I said yes and he said why is it that I have never seen a San member of the community owning hundred herds of cattle besides Royal /Ui/o/oo? This is an informed person, very informed. He listens to the radio. He knows all of you. He has not seen you, but he knows who the Ministers are.

Venaani gave an anecdote to his audience before he argued how the San people can be assisted in alleviating poverty. The San tribe is one of the few marginalised tribes in Namibia. These people have been living in abject poverty since the colonial era. In his argument, he stated that instead of giving the San people cattle they should be provided with employment relevant to the skills they have, such as hunting. His aim was to show that even people on farms know that the San people do not keep cattle for a long time, thus the strategy of providing them with cattle to eradicate poverty will not work. In his speech, Venaani appealed to the audience's pathos by saying that "He knows all of you. He has not seen you, but he knows who the Ministers are." He touched the emotions of the ministers who are among the audience in parliament.

In addition, a complaint can be given in a form of an anecdote as follows:

Hon. Maamberua: The congratulatory advert by UNAM newspapers of Thursday, 02 April 2015 caught my attention because this publicly funded institution has used these funds to place adverts to congratulate members of the Ruling Party who have made it to the Legislature and to Cabinet. My question to the Minister needs to be contextualized in my relationship with UNAM, because I am not an obscure, non-entity insignificant persona who could easily have been forgotten. Despite the facts that an UNAM official came to interview Parliamentarians, including me at Parliament to confirm who had worked or studied at UNAM, I a SWANU member was nevertheless excluded from the advert in reference...... Why did UNAM choose to congratulate only SWAPO MPs?

In Maamberua's anecdote, the last statement is an indirect speech act, which carries an illocutionary force of a complaint. Maamberua might have assumed or have known already the reason why he was ommited, however, he included the question in his narration. His anecdote might have touched the audience's emotions. When he said "I am not an obscure, non-entity insignificant persona who could easily be forgotten", he reminds the audience of his valuable contribution to UNAM through his work. In his anecdote he also shows that there was injustice done to him when he was interviewed with other MPs but then, excluded from the advert. It can be assumed that he was left out on the basis that he is an opposition party MP, whilst the rest of the MPs included are from the ruling party (SWAPO). In this case, his version can be attributed to the position he holds as the leader of an opposition party (SWANU). Sharing his disappointment through this anecdote with fellow MPs is likely to move the emotions of some, especially those who could relate to his academic contribution to the University of Namibia (UNAM).

In another anecdote, Kawana showed that the issue of being understaffed at the Office of Presidential Affairs in Namibia can be dealt with by looking at other countries, based on his visit. He wants the Namibian government to put itself in the shoes of that country for a convenient operation in the Office of the Presidential Affairs. His experience can also be attributed to the position that he held previously as the Minister of Presidential Affairs: 


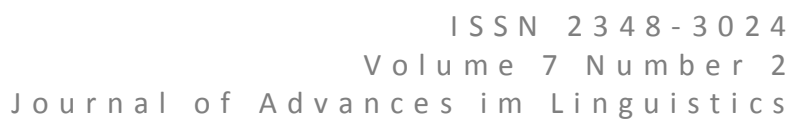

Hon. Kawana: I had an opportunity to visit the Office of the Minister of Presidential Affairs in one of our neighbouring countries.., but it is one of those countries which we always praise as one of the shining examples of democracy where the office of the Minister of Presidential Affairs has seven Permanent Secretaries under him and each Permanent Secretary has a number of what we call personnel. Compare that with our State House, it is really nothing. It is totally under-staffed and I think that as time goes on we will need to get, and I agree with Honourable Venaani, professional people in all the departments.

An anecdote can be given in a form of any classification of speech acts, but are mostly used as an assertive speech act. This is because the statement of the narration that the speaker gives can be either true or false. Assertives are the most common illocutionary acts used because they simply state how something is in the world. According to Akinwotu (2013), "assertives commit speakers to the truth of some proposition, e.g. dictating, claiming, reporting, announcing, etc" (p. 45). However, these utterances may be true or false. In the same vein, Jarraya (2013) defines assertives as "representatives represented by the speaker's assertion of the truth of what is said, as in giving conclusions, complaining, boasting or describing events or states in the world" (p. 9). Assertives such as claims, facts, reports, proof, description, explanation, clarification, were observed in parliamentary debates.

\section{Attacks and Praises}

Speech acts of attacks and praises may be both used as rhetoric in speeches. Praises and attacks are known as epideictic rhetoric. Kangira and Mungenga (2012) state that, "the aim of epideictic rhetoric is either to praise or blame" (p. 111). Attacks are persuasive when the speaker discredits his/her opponent by attacking an individual instead of the idea the individual may represent. Benoit and Williams (as cited in Kangira, 2005), describe persuasive attacks as "messages that attempt to damage the image (reputation, face, identity) of a person, group or organization...."(p. 44). On the other hand, praising someone by accrediting, congratulating or giving a brief account of their achievements may also be persuasive to the audience. According to Kalariova (2015), in order to unite the audience against the opponent, a strategy of blaming others is used by the speaker in his address. The following dialogue illustrated some degree of shaming in the response:

Hon. Sioka: I am getting confused, Honourable Chairperson, because I think the discussion about marginalised people falls under the Prime Minister not President.

Hon. Venaaani: You do not even know how Government is functioning. Sit down. It has been shifted with the new Government, not the old.

Venaani belittled his fellow MP by saying he does not know how the government is functioning and orders him to sit down. This may be regarded as a face-threatening-act (FTA). Chelaru-Muraru (2012) states that, "the speaker launches violent FTAs on his opponents and enjoys exhibiting his verbal power and aggressiveness by means of directive and commissive speech acts of command, interdiction or threat, as well as by irony, insults...." (p. 167). Although these statements were uttered in a peaceful environment during parliamentary debates, they may play on personal emotions of the target audience and affect them negatively. According to llie (2013), a Norwegian social psychologist discovered that the technique of blaming and shaming can cause embarrassment and it discourages the actual sense of tackling the issue at hand. Ilie (2013) further states that blaming and shaming encourages these individuals to accept their lowered status by embarrassing them before other members of parliament. Sometimes an opinion or an idea may be disputed by praising the person first than later expressing objection. Such a statement might be regarded as ironical:

Hon. Nambahu: Honourable Venaani, I think you are making an important point, but do you not think that a proper study would probably be the answer to the first question....?

Although Nambahu felt that Venaani should reconsider his point, he remarked on the importance of his point. He praised him first, subsequently, disputed his idea. In this situation, Nambahu seemed to convince his target audience (Venaani) to re-consider the opinion he gave. Moreover, speech acts that carry a force of commending and congratulating are also praises. Schlettwein commended the Official Opposition Party for their contribution towards the development of the country.

Hon. Schlettwein: I recognise the Opposition Parties, especially the Official Opposition Party, and want to thank them in advance for the positive contribution in the common responsibility for advancing the socio-economic development agenda for our country.

The ideas shared by Schlettwein after acknowledging the opposition parties are likely to be taken positively, because the parties are praised and thus motivated to continue contributing. Similarly, Mwaningange congratulated the work accomplished by the Ministry of Foreign Affairs in order to encourage it to continue doing well:

Hon. Mwaningange: Firstly, may I congratulate the work well done and still being done by the Ministry of Foreign Affairs with regard to improving the working conditions and the political diplomatic working cooperation environment where our Namibian Diplomats are operating.

A congratulatory remark as such does not only encourage the team in the Ministry in their work, but also motivates them. Although he might have other issues to raise related to that Ministry, he used the technique of lifting their spirit first so they can be able to accommodate his speech with a positive attitude. The technique of congratulating the audience is very crucial in persuading the listeners. Shixwameni used the word salute to show appreciation to Namibians in foreign missions. He praised them by showing that they are doing a good job so far, thus their allowances need to be revisited. 


$$
\begin{array}{r}
\text { ISSN 2348-3024 } \\
\text { Jolume } 7 \text { Number } 2 \\
\text { Journal of Advances im Linguistics }
\end{array}
$$

The phrase the cost of living is so high evokes emotions. Shixwameni used this speech act to appeal to the pathos of the audience to sympathise with the Namibians living in costly countries.

Hon. Shixwameni: I actually rise to support this particular Vote and I have three issues that I want us to address. One is to salute the men and women in our Foreign Missions for conducting themselves professionally, in representing Namibia. Secondly is to really consider the living allowances for these men and women abroad, because some of them are in countries where the cost of living is so high that it basically needs to be revisited.

Dlugan (2010) believes that pathos is the quality of persuasion which interests the emotions of the audience. Pathos is triggered whenever these emotions are invoked and the addressee is likely to achieve the goals in question. According to Dlugan (2010), the Greek philosopher Aristotle claims that logos is the most important appeal amongst all three.

As mentioned earlier in this section that rhetorical attacks are messages that attempt to damage the image of a person or a group, following are two examples of persuasive attacks between political parties taken from a Presidential Rhetoric article. According to Kangira (2005), in an election campaign in Zimbabwe, ZTV repeatedly screened Tsivangirai's (MDC, Opposition leader) rally address saying: If you (Mugabe) don't go peacefully, we will remove you violently. This statement serves as a threat in a form of a directive telling Mugabe to leave the presidency. This was an attempt to create an impression that Tsivangirai plotted to kill Mugabe. The repetitive screening was possibly made to persuade the voters that Tsivangirai was violent and will not be suitable for the presidential position. On the other hand, Kangira (2005) mentions that in one of its advertisements, the MDC asked a rhetorical question: The oldest president in history? This was a rhetorical attack based on Mugabe's age. The advert went on saying: This election is your last chance to vote for new ideas instead of old thinking. This was another attempt to persuade the voters that it is better to vote for younger candidates than the older ones. In this regard, the MDC took advantage of Mugabe's advanced age (78).

\section{Metaphors}

Metaphors are tools used by members of parliament as rhetorical devices. According to Kampka (2013), a metaphor as a rhetorical device is used by politicians when defining a situation. In addition, she states that defining a situation is the first stage of a successful persuasive strategy. Kelle (2005) defines a metaphor as "a decorative way of saying something that can be equally expressed by a literal statement" (p. 35). According to Searle (1979), the relationship between words and sentence meaning in metaphors is a problem, whereby the sentence meaning might be different from the speaker's meaning. Metaphors that may carry an illocutionary force of warning, may be performatives.

Although there are old and common metaphors, anyone can be creative in devising metaphors. Charteris-Black (2005) argues that "because metaphor is an aspect of language use, any word form can be a metaphor if the context makes it as such" (p. 14). Davidson (2008) states that "there are no instructions for devising metaphors; there is no manual for determining what a metaphor means or says" (p. 390). In support of metaphors as an effective way of persuading an audience, Charteris-Black (2009) argues successful and charismatic leaders produce metaphors on which the audience imagine their own meanings and get a degree of socio-psychological and emotional gratification. Archakis and Tsakona, (2010) highlighting the importance of metaphors in politics, state, "the political metaphor is essential to persuasiveness, since it offers new and simpler conceptualisations for complex or problematic notions and activates positive or negative connotations aroused by the words used in it..." (p. 919). Mbenzi (2014) asserts that a metaphor is "seen as a tool in rhetoric to stir up emotions" (p. 229). In her statement below, Dienda used the term 'greener pastures' to refer to a place better than the Ministry under discussion:

Hon. Dienda: I am asking this question because after you have trained them, these people left the Ministry to look for greener pastures.

By using this metaphor, she linked a better situation with greener pastures, creating a visual image in the audience's minds thus making them perceive and think that the trainees are leaving the ministry to go to better places. This device is effective because it triggers the human mind to see things in a different way. For instance, if the speaker relates to something which is disgusting, then the mind sees it that way and, if it is to something beautiful or precious, it will also be perceived that way. Charteris-Black (2005) states that metaphor has impacts on our beliefs, attitudes and values because it activates unconscious emotional associations.

According to Mbenzi (2014), Aristotle acknowledged the significance of rhetoric in speeches. Biblical metaphors are said to be persuasive speech acts, thus used by many prominent political leaders in their speeches. The following example features three metaphors:

Hon. Ndakolo: It is important to take cognisance that among the main drivers of the current defence expenditure is the fact that the Namibian Defence Force (NDF) comprises of former soldiers of the People's Liberation Army of Namibia (PLAN) and the South West African Territorial Force (SWATF). This "Old Guard" is on the verge of massive exit from the Force. The Exodus of NDF veteran soldiers started in earnest in the past five years and will continue for the Medium Term Expenditure Framework (MTEF). The "new blood" that has been injected into the Force since 1996, will be the main backbone of the Force and they will need intensive and long-term training and preparation.

To emphasise his message, Ndakolo, the Minister of Defence Force used the term Exodus to refer to the exiting of old soldiers from the Force. He related the exiting of veteran soldiers with the biblical story of Exodus (the departure of the Israelites from Egypt). In addition, he also applied metaphorical language by saying new blood to refer to young people and old guard to the old. According to Davidson (2008), "a metaphor makes us attend to some likeness, often a novel or 


$$
\begin{array}{r}
\text { ISSN 2348-3024 } \\
\text { Jolume } 7 \text { Number } 2 \\
\text { Journal of Advances im Linguistics }
\end{array}
$$

surprising likeness between two things" (p. 391). Through this strategy, Ndakolo attempted to persuade the audience by showing them the importance of recruiting young people and allowing those who have served long to leave the Force. Given that there is a high rate of unemployment in Namibia, this statement embraces a strong rhetoric that is said at the right time. Although his speech had no association with his role or position as the head of the Ministry, he evoked the emotions of the audience when he mentioned the youth of Namibia (young blood) who are in dire need of jobs, thus, winning the hearts of his audience.

Another metaphor used was the cream of Africa. The best and qualified youths were metaphorised as the cream of Africa as shown below:

Hon. Kawana: We are losing a lot of people, the cream of Africa-the youths that are perishing in those high seas because they are running away from Africa in search of a better life somewhere else. It is a shame because those youths are the ones who were supposed to develop this Continent.

Generally, the cream is the best part of milk. Here Kawana emphasised the talent and skill of youth in Africa. Currently, there are many challenges facing Namibian youth such as unemployment, land accessibility and high cost of education. Therefore, he appealed to the ethos of the audience to show that he cares about them and would like them to be involved in the development of Africa. This enabled the audience to have trust in him and see him as a credible person. According to Dlucan (2010), there are many ways of building credibility. Dlucan (2013) further states that in order to appeal for ethos, one should ask him/herself whether he is respected by the audience; whether the audience perceives him as a good character; whether he is trusted by the audience; and whether the audience believe in their content knowledge of the speech.

Like any other speech act, metaphors can be used as assertive speech acts as shown below. In this assertive, the word bleeding was metaphorised as the action of exploiting or defrauding the Namibian economy.

Hon. Tweya: The economy is bleeding and we have these so-called Namibians that are bleeding our economy.

The word bleeding has a negative connotation. It is associated with suffering. The word can stir up the audience's emotions because of the connotation it holds. According to Charteris-Black (2005, p. 14), "metaphorical meaning is determined by the sorts of connotations aroused by the words in their normal non-metaphorical or literal use."

Another speech act that can be attributed to metaphors is the one that represents a simile as shown below. Namupala metaphorised the sick body with the whole society being affected.

Hon. Namupala: If one part of the body is sick then the whole body is sick.

\section{Emotional appeal}

Emotional appeal plays on audience's emotions such as fear, pity, sympathy, insecurities and hope. The perlocutionary act (effect) that emotional appeal has enables the listener to react according to the illocutionary act. For example Shanghala who is a newly appointed Attorney General seemingly tried to capture the audience's attention by showing pathos:

Hon. Shanghala: I may not be popular among my comrades, let alone who think of me as unqualified to hold this office. None of that matters, and it is known it does not bother me in the slightest.

In this speech act, Shanghala brought in his office (position) to appeal to the audience's emotions. He wanted the audience to sympathise with him as he feels there are some people who are not happy about his promotion. This is an expressive speech act that Shanghala gave. He expresses his feelings in which he seemingly feels pity for himself in order for the audience to play along with his strategy. Another example of touching on the audience's emotion is that of Kaapala:

Hon. Kaapala: We fought for our pensions on our own for a very long time until we understood that it was so difficult for us to get through to government. We also have other people in this country, the workers, people that we call miners from Tsumeb Copper Mine Limited whose pension fund was also shamefully stolen.

Kaapala touched the audience's emotions by reminding them of the pension fund that the public members fought for and which was still not recovered. By reminding the audience, Kaapala performs an action (performative). He uses the word we to include himself in the group he is talking about, as there might be other MPs who went through the same predicament as himself. In his short account, as an opposition party MP, he thinks injustice was done by the government. The illocutionary force (message) carried in Kaapala's version is that they fought a battle that ended in vain. It can be concluded that the fact that he is an opposition MP, instigated him to blame the government.

In another instance, Witbooi metaphorised the feeling of pity and sympathy with bleeding. In his statement, he also tried to evoke the audience's emotions so they sympathise with him:

Hon. Witbooi: When I say my heart is bleeding for the communal farmers, I really mean it. Something must be done to rescue and assist our communal farmers.

Words such as assure, can be used for the purposes of inspiring belief in someone. This is a commissive statement which may have an emotional impact on those who have been doubting the educational status of some tribes in Namibia. 


$$
\begin{array}{r}
\text { ISSN 2348-3024 } \\
\text { Jolume } 7 \text { Number } 2 \\
\text { Journal of Advances im Linguistics }
\end{array}
$$

Hon. Jagger: When it comes to the San, Ovatue, Ovatjimba, Ovahimba, and the Hai//kom, I can assure this House today that the Government has done a lot for these communities.

Jagger used the word assure possibly to create an impression that she is credible and that the audience need not to worry about the education of these tribes as it has been taken care of by the government.

\section{SYNOPSIS}

This paper analysed speech acts used in the Namibian parliamentary debates. Three types of speech acts were introduced by Austin (1962), namely, locutionary, illocutionary, and perlocutionary. Austin's (1962) theory of speech acts claims that all utterances with their meanings perform actions through certain forces. The speech acts discussed in this paper were used by MPs from different political parties. Various Illocutionary speech act classifications (derived from one the Austin's three types), known as Searle's speech acts classifications were used in parliamentary debates. These speech act classifications are assertives, directives, commissives, expressives, and declaratives. These speech acts were discussed under seven rhetorical devices. Some speech acts were used indirectly to persuade MPs and the general public.

There is a tendency of some MPs using rhetoric language in oblivion. However, some MPs deliberately used rhetoric to verbally influence the audience or win arguments in parliamentary proceedings. Furthermore, the findings of this paper also showed that regardless of the types of speech act they uttered, the MPs were capable of using a variety of rhetorical devices in their debates. Performatives and constatives played a major role in this paper since most of the MPs utterances were either a speech act with a performance or an ordinary statement with a message, for example: May congratulate the work well done and still being done by...., and Higher education is such a critical area that we cannot afford to sidestep, respectively.

Generally, rhetorical questions played an important role in parliamentary proceedings, as some questions arise in an interference manner. Rhetorical questions do not necessarily require answers, they rather make a statement. It could be assumed that using these kinds of questions could be the easiest way of expressing oneself towards persuading an audience. Some of the questions were sarcastic while others were mocking. Giving evidence is one way of persuading listeners as facts, figures, and documents speak for themselves. The strategy of using evidence may mean that the speaker presents documents or any reliable source pertaining to what is being presented. Another way of persuading an audience was the use of inclusive language. A number of pronouns such as we, us, our, Namibians, united, together, can be used to show unity and solidarity, especially when discussing burning issues in the society. This implies that the speaker feels for the people involved, thus including him/herself. It can also be concluded that this tends to give the audience especially the general public who are viewing and listening to these proceedings, a sense of unity and togetherness. According to Kangira (2007), the aforesaid words are called Together-words.

An anecdote is storytelling or a narration of one's experience. Research shows that an anecdote can be used as a persuasive strategy. A number of MPs used anecdotes to give their experiences or tell their stories. They used anecdotes to relate to the topics in discussion or under debate. Once again, attacks and praises play an important role in parliamentary debates. One reason could be to shame and blame the opposition in order to look bad in the eyes of the audience; and to tribute, complement and commend. This strategy is where unparliamentary language is concerned.

Furthermore, using mataphors may be an effective way of getting attention from the audience. The use of figures of speech enables the audience to conspicuously fathom the gist of the message. In some cases, when metaphors are used, the message is not correctly interpreted by the listeners. The last device discussed in this paper was emotional appeal. Usually, the speaker attempts to speak in order to get sympathy from the audience (pathos) or use sensitive words to touch their emotions. This strategy is also used to remind or awaken the audience on past bitter or good memories. Research shows that this is mostly used in political campaigns.

Persuasive strategies originate from three modes of persuasion. These three modes were introduced by Aristotle, namely, ethos (character), pathos (emotions), and logos (reasoning). It was found that some speech acts that MPs used as persuasive strategies were negative, which belittled other MPs. On this note, it is recommended that MPs receive guidelines on using more powerful persuasive strategies when attempting to persuade their audience. Although it is almost impossible to get every MP use the same strategies, having guidelines regarding rhetorical communication in place, will create a conducive environment for debating, where all MPs treat each other with respect, so that no one feels offended or shamed.

\section{CONCLUSION}

This paper analysed speech acts used in the Namibian parliament. Three types of speech acts were introduced by Austin (1962), namely, locutionary (what is uttered), illocutionary (the message within the utterance), and perlocutionary act (the effect that the message has on the listener). From the illocutionary act, five categories of speech acts were drawn, namely: assertives, directives, commissives, expressives, and declaratives. The analysis of the speech acts in this paper shows that MPs are neither always aware of the types of speech acts they are using nor the rhetoric within their speech acts. These speech acts were analysed under rhetorical devices, namely: questions, evidence, inclusive language, anecdote, attacks and praises, metaphors, and emotional appeal. 


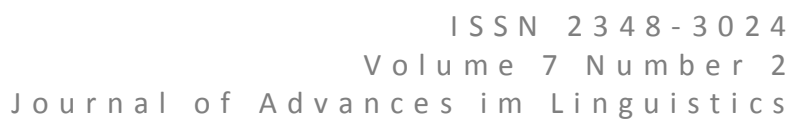

Performatives and constatives were used in parliamentary debates, but performatives are used frequently. Performatives are those that carry a performance, and constatives are those that have a message but do not necessarily carry a performance. This analysis was guided by two theories, Austin's Speech act theory, and Aristotle's theory of rhetoric. These speech acts were explained by means of the three modes of persuasion, namely, ethos, pathos, and logos.

In conclusion, parliamentarians, through their discourse, generally promote good governance by contributing and making decisions from the debates that take place within the House. They are capable of using a variety of persuasive strategies during parliamentary debates. After all, from their heated debates, MPs are supposed to come to a common understanding and make informed decisions, thus a great need for them to be good communicators.

\section{APPENDIX}

Hon. Dienda- MP (DTA-Opposition)

Hon. Ekandjo- Minister of Sport, Youth \& National service, Cabinet member

Hon. livula-Ithana- Minister of Home Affairs, Cabinet member

Hon. Jagger- MP (SWAPO-Ruling)

Hon. Kaapala- MP (WRP-Opposition)

Hon. Kandjii-Murangi- Minister of Higher Education, Cabinet member

Prof. Katjavivi (Chairperson of the Whole House Committee)

Hon. Kavekotora- MP (RDP-Opposition)

Hon. Kawana- Minister of Justice, Cabinet member

Hon. Maamberua- MP (SWANU-Opposition)

Hon. Mbumba- Secretary General (SWAPO-Ruling)

Hon. Mwaningange- Deputy Minister of Defence

Hon. Nambahu- Deputy Minister of Environment \& Tourism

Hon. Namupala- MP (SWAPO-Ruling party)

Hon. Nandi-Ndaitwah- Deputy Prime-Minister, Cabinet member

Hon. Ndakolo-Minister of Defence, Cabinet member

Hon. Schlettwein- Minister of Finance, Cabinet member

Hon. Shanghala- Attorney General, Cabinet member

Hon. Shixwameni- MP (APP-Opposition)

Hon. Sioka- Minister of Gender Equality \& Child welfare, Cabinet member

Hon. Smit- MP (DTA-Opposition)

Hon. Tweya- Minister of Information and Communication Technology, Cabinet member

Hon. Venaani- President of the official opposition party (DTA)

Hon. Witbooi- Deputy Minister of Gender Equality \& Child welfare

\section{REFERENCES}

1. Akinwotu, S. A. 2013. A speech act analysis of the acceptance of nomination speechless of Chief Obafemi Awolowo and Chief M. K. O Abiola. English Language Linguistics Research, 2(1), 43-51.

2. Arachakis, A., \& Tsakona, V. 2010. The wolf wakes up inside them grows werewolf hair and reveals all their bullying: The representation of parliamentary discourse in Greek newspapers. Journal of Pragmatics, 42, 912923.

3. Austin, J. L. 1962. How to do things with words. (J. O. Urmson, Ed.), Oxford: Clarendon.

4. Ayeomoni, O. M. \& Akinkuolere, O.S. 2012. A pragmatic analysis of victory and inaugural speeches of President Umaru Musa Yar' Adua. Theory and Practice in Language Studies, 2(3), 461-468.

5. Charteris-Black, J. 2005. Politicians and rhetoric: The persuasive power of metaphor. New York, NY: Palgrave Macmillan. 


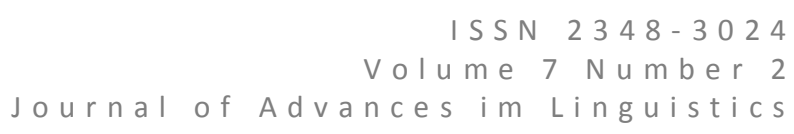

6. Charteris-Black, J. 2009. Metaphor and political communication. In A. Musolff (Eds.), Metaphor and discourse. (pp. 97-115). UK: Palgrave Macmillan.

7. Chelaru-Murarus, O. 2012. Style and rhetorical strategies in the discourse of a Romanian Nationalistic Party: A case study Corneliu Vadim Tudor's parliamentary speeches. In L. Ionescu-Ruxandoiu (Ed.), Parliamentary discourse across cultures: Interdisciplinary approaches (pp. 151-172). New Castle: Cambridge Scholars Publishing.

8. Chen, H. J. 2006. A study of pragmatic prototypical categories of rhetorical questions. Shiying: Jinzhou, Liaoning

9. Chivero, E. 2012. Language and gender: An examination of the linguistic strategies used by male and female members of parliament during parliamentary debates carried out between 2005 and 2007in the house of assembly. Unpublished doctoral dissertation, University of Zimbabwe, Zimbabwe.

10. Davidson, D. 2008. What metaphors mean. In S. Nuccetelli \& G. Seay (Eds.), Philosophy of Language (pp. $390-$ 402). USA: Rowan \& Littlefield Publishers, Inc.

11. Dlugan, A. 2013. Ethos, pathos and logos: 3 pillars of public speaking. Six minutes, 2.

12. Frank, J. 1990. You call that a rhetorical question: Forms and functions of rhetorical questions in conversation. Journal of Pragmatics, 14(5), 723-738.

13. Habinek, T. 2005. Ancient rhetoric and oratory. USA: Blackwell Publishing.

14. Han, C. 2002. Interpreting interrogatives as rhetorical questions. Lingua. 112(3), 201-229.

15. Ilie, C. 2002. Discourse and metadiscourse in parliamentary debates. Journal of Language and Politics, 2(1), 7192.

16. Ilie, C. 2003. Parenthetically speaking: Parliamentary parentheticals as rhetorical strategies. In M. Bondi \& S. Stati (Eds.), Current Studies in Dialogic Communication (pp. 253-264). Tubingen: Max Niemeyer Verlag.

17. Ilie, C. 2010. Identity-co construction in parliamentary discourse practices. In C. Ilie (Eds.), European Parliaments under scrutiny (pp. 57-79). Amsterdam: John Benjamins Publishing Company.

18. Ilie, C. 2013. Gendering confrontational rhetoric: Discursive disorder in the British and Swedish parliaments. Democratization, 20(3), 501-521.

19. Jarraya, S. 2013. Persuasion in political discourse: Tunisian president Ben Ali's last speech as a case study.

20. Johnstone, B. 1989. Linguistic strategies and cultural styles for persuasive discourse. Language, Communication, and Culture: Current Directions, 139-156.

21. Kampka, A. 2013. Rhetoric of the crisis: Polish parliamentarian debates on the future of the EU. In G. Kisicek, \& I. Z. Zagar (Eds.), What do we know about the world: Rhetorical and argumentative perspectives (pp. 178-203). Canada: Open Monograph Press.

22. Kangira, J. 2005. Negative advertising as a strategy of persuasion in the 2002 presidential election campaign in Zimbabwe. Zambezia: The Journal of Humanities of the University of Zimbabwe, 32(1), 41-63.

23. Kangira, J. 2007. The sun that never rose: A rhetorical analysis of the July 2006 sunrise of currency reform monetary policy review statement issued by the Governor of the Reserve Bank of Zimbabwe. Nawa Journal of Language and Communications, 23-30.

24. Kangira, J. \& Mungenga, J. N. 2012. Praiseworthy values in President Hifikepunye Pohamba's epideictic speech marking Namibia's $20^{\mathrm{th}}$ anniversary of independence. Journal for Studies in Humanities and Social Sciences, 1(1), 109-116.

25. Karaliova, T. 2015. Let them talk: New Year's presidential rhetoric in Russia, Belarus and Poland. Journal of Communication Inquiry, 40(2), 145-161.

26. Kelle, B. E. 2005. Hosea 2: Metaphor and rhetoric in historical perspective. Atlanta, USA: Society of Biblical Literature.

27. Langton, R. 1993. Speech acts and unspeakable acts. Philosophy \& Public Affairs, 22(4), 293-330.

28. Levinson, S. C. 1983. Pragmatics. New York, NY: Cambridge University Press.

29. Mbenzi, P. A. 2014. The political rhetoric of Bishop Kleopas Dumeni in the pre-independence era in Namibia. University of Namibia. Namibia. 
30. Nuccetelli, S. \& Seay, G. 2008. Philosophy of language: The central topics. United Kingdom: Rowman \& Littlefield Publishers, Inc.

31. O'Driscoll, J. 2007. What is an FTA: Reflections on a chance meeting with Claudine. Journal of Politeness Research, 3(2), 243-268.

32. Palonen, K. 2016. From oratory to debate: Parliamentarisation of deliberative rhetoric in Westminster. Germany: Nomos.

33. Republic of Namibia Parliamentary Debates. National Assembly. 2015. Vol. 168. 36.

34. Republic of Namibia Parliamentary Debates. National Assembly. 2015. Vol. 169. 41.

35. Republic of Namibia Parliamentary Debates. National Assembly. 2015. Vol. 171. 119.

36. Republic of Namibia Parliamentary Debates. National Assembly. 2015. Vol. 173.

37. Rorty, A. O. 1996. Structuring rhetoric. In A. O. Rorty (Ed.), Essays on Aristotle's rhetoric (pp. 1-33). Berkeley: University of California Press.

38. Searle, J. 1979. Expression and meaning. USA: Cambridge University Press.

39. Silvestre-Lopez, A. J. 2004. John Kerry's political rhetoric: An account of the main rhetorical features of his oral delivery. Jornades de Forment de la Investigacio, 1-20.

\section{Author' biography with Photo}

Justina Meluwa Latenda Amakali is a Doctoral student at the University of Namibia. She is also an English full-time lecturer at the Language Centre at the University of Namibia. She holds a Master of Philosophy (Second Language Studies); a Honors Degree in Education, Training, and Development; and a few Diplomas in English Language Teaching.
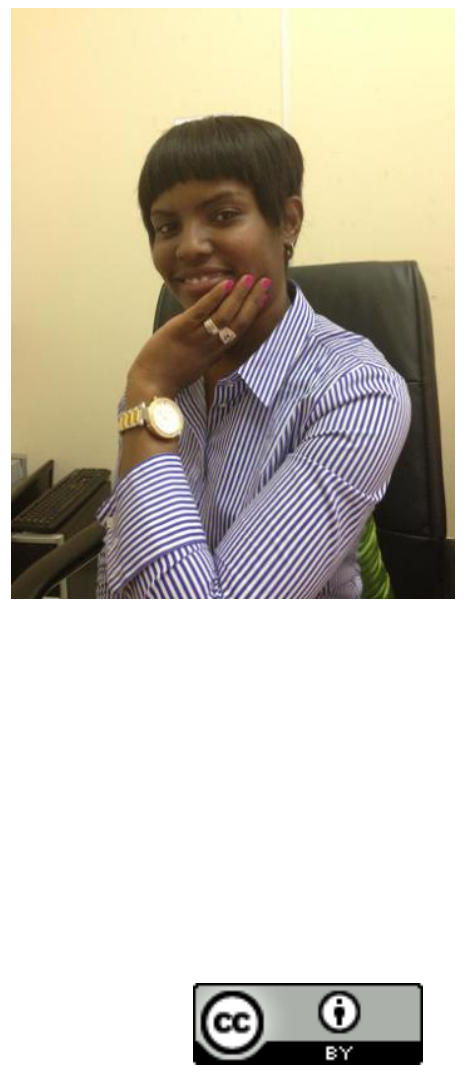

This work is licensed under a Creative Commons Attribution 4.0 International License.

DOI : $10.24297 / j a l . v 7 i 2.5156$ 
ISSN $2348-3024$

Volume $7 \mathrm{Number} 2$

Journal of Advances im Linguistics

$1218 \mid \mathrm{P}$ a g e

November 2016

https://cirworld.com/ 